\title{
Sediment-water inorganic nutrient exchange and nitrogen budgets in the Colne Estuary, UK
}

\author{
Daniel C. O. Thornton ${ }^{1,2, *}$, Liang F. Dong ${ }^{1}$, Graham J. C. Underwood ${ }^{1}$, \\ David B. Nedwell ${ }^{1}$
}

${ }^{1}$ Department of Biological Sciences, University of Essex, Colchester, Essex CO4 3SQ, UK

${ }^{2}$ Present address: Department of Oceanography, Texas A\&M University, O\&M Building, 3146 TAMU, College Station, Texas 77843-3146, USA

\begin{abstract}
The exchange of dissolved inorganic nutrients $\left(\mathrm{NO}_{3}{ }^{-}, \mathrm{NO}_{2}{ }^{-} \mathrm{NH}_{4}{ }^{+}, \mathrm{PO}_{4}{ }^{3-}\right.$ and $\left.\mathrm{SiO}_{3}{ }^{-}\right)$was measured across the sediment-water interface at 4 sites along the Colne Estuary at monthly intervals between August 1996 and March 1998 in the dark and under illumination. Fluxes across the sediment-water interface were scaled up to calculate nutrient budgets for the whole estuary, accounting for the area of sediment exposed to illumination. Sediments were a net sink of $-16.28 \mathrm{Mmol} \mathrm{N} \mathrm{yr}^{-1}$ for oxidized inorganic nitrogen $\left(\mathrm{NO}_{3}{ }^{-}+\mathrm{NO}_{2}{ }^{-}\right)$. Mean nitrate fluxes across the sediment-water interface were -329 and $-91 \mu \mathrm{mol} \mathrm{m} \mathrm{m}^{-2} \mathrm{~h}^{-1}$ in the dark and light respectively. Colne sediments were a source of ammonium in the dark (12.4 $\left.\mathrm{Mmol} \mathrm{N} \mathrm{yr}^{-1}\right)$. Illumination reduced ammonium flux into the overlying water or affected uptake due to assimilation by the microphytobenthos and a stimulation of nitrification. Mean ammonium fluxes across the sediment-water interface were 399 and $-169 \mu \mathrm{mol} \mathrm{m}^{-2} \mathrm{~h}^{-1}$ in the dark and light, respectively. Consequently, sediments were a net sink for ammonium in the light $\left(-0.31 \mathrm{Mmol} \mathrm{N} \mathrm{yr}^{-1}\right)$. Similarly, illumination affected silicate exchange across the sedimentwater interface, with silicate flux into the overlying water reduced or reversed under illumination compared to the dark. The estuarine sediments were a net source of silicate (6.09 $\left.\mathrm{Mmol} \mathrm{yr}^{-1}\right)$ and

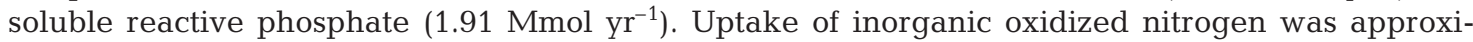
mately balanced by adding together ammonium flux and denitrification supported by nitrate in the overlying water. This mass balance indicates that dissimilatory nitrate reduction to ammonium (DNRA) was a significant process in the sediments of the Colne Estuary. Fluxes in the light accounted for less than $6 \%$ of the total sediment-water exchange of both ammonium and nitrate. However, a large proportion of the $-15.49 \mathrm{Mmol} \mathrm{N} \mathrm{yr}^{-1}$ of oxidized inorganic nitrogen taken up by the sediment in the dark was cancelled out by a flux of $12.4 \mathrm{Mmol} \mathrm{N} \mathrm{yr}^{-1}$ into the overlying water as ammonium. Net dissolved inorganic nitrogen (DIN) fluxes were $-3.09 \mathrm{Mmol} \mathrm{N} \mathrm{yr}^{-1}$ in the dark and $-1.17 \mathrm{Mmol}$ $\mathrm{N} \mathrm{yr}^{-1}$ in the light, as fluxes of all nitrogen species were negative under illumination. Therefore fluxes under illumination accounted for $28 \%$ of the net uptake of DIN by estuarine sediments in the Colne Estuary, despite the short time periods and small area of sediment under illumination. In macrotidal estuaries such as the Colne, where microphytobenthos are abundant, light plays an important role in moderating sediment-water nutrient exchange.
\end{abstract}

KEY WORDS: Ammonium - Denitrification - Dissimilatory nitrate reduction to ammonium (DNRA) · Flux $\cdot$ Nitrate $\cdot$ Phosphorus $\cdot$ Silicon $\cdot$ Estuarine

Resale or republication not permitted without written consent of the publisher

\section{INTRODUCTION}

Nutrient cycling in estuaries is intense and affects both the absolute and relative concentrations of inorganic nutrients, and ultimately the flux of inorganic nutrients from land to ocean. Extrapolating the nutrient loading from rivers to the coastal ocean is not straightforward (Nedwell et al. 1999) due to the large number of competing and interacting physico-chemical and biological processes that occur along estuarine gradients. A significant proportion of the inorganic nitrogen entering the coastal ocean passes through estuaries, where it is transformed by bacterial mediated metabolic processes. Processes which result in the 
chemical reduction of dissolved oxidized inorganic nitrogen include denitrification, anammox (anaerobic oxidation of ammonium; Dalsgaard et al. 2005) and dissimilatory reduction of nitrate to ammonium (DNRA). Denitrification is carried out by facultative anaerobic bacteria using nitrate (or nitrite) to respire organic matter, resulting in a loss of biologically available nitrogen from estuarine sediments to the atmospheric sink as $\mathrm{N}_{2}$ and to a lesser extent the greenhouse gas $\mathrm{N}_{2} \mathrm{O}$ (Nedwell et al. 1999). Nitrification is an aerobic process during which chemoautotrophic bacteria derive energy from the oxidation of ammonium to nitrate. This energy is used to fix inorganic carbon. Nitrification occurs in the oxic zone at the sediment surface, whereas denitrification occurs in anoxic sediment immediately below the oxic zone. Although nitrification and denitrification are spatially separated, the 2 processes are often coupled as nitrate generated through nitrification diffuses down into the sediment where it is used as a terminal electron acceptor by denitrifying bacteria (Rysgaard et al. 1994, Dong et al. 2000). Denitrification in estuarine sediments often removes a significant proportion of the dissolved inorganic nitrogen (DIN) load fluxing through an estuary (Seitzinger 1988, Nedwell \& Trimmer 1996) and thereby plays an important role in ameliorating coastal eutrophication. Estimates for DIN removal in the Colne Estuary are 18 to $27 \%$ by Ogilvie et al. (1997) and 20 to $25 \%$ by Dong et al. (2000). Concentrations of both nitrate and ammonium are high in the Colne, occasionally exceeding $1 \mathrm{mM}$ in the water column (Dong et al. 2000, 2002, Thornton et al. 2002); therefore denitrification is a sink for a large amount of biologically available nitrogen in this hypernutrified estuary. DNRA is a significant process in coastal sediments (Gardner et al. 2006), although it is often overlooked in studies of coastal nitrogen cycling as, unlike denitrification and anammox, it does not lead to a loss of bioavailable nitrogen from the ecosystem to the atmosphere. DNRA potentially competes with denitrification for oxidized inorganic nitrogen $\left(\mathrm{NO}_{3}{ }^{-}\right.$or $\left.\mathrm{NO}_{2}^{-}\right)$. Furthermore, DNRA makes nitrogen more bioavailable through the reduction of oxidized inorganic nitrogen to ammonium, which can be directly assimilated by microorganisms without the requirement of assimilatory $\mathrm{NO}_{3}^{-}$or $\mathrm{NO}_{2}^{-}$reductase enzymes.

The relatively high nutrient concentrations within estuaries often support significant benthic primary productivity, usually dominated by photosynthesis by microphytobenthos (MPB), with lesser contributions from chemoautotrophic nitrifying and anammox bacteria. Estuarine MPB have primary production rates in the range 47 to $314 \mathrm{~g} \mathrm{C} \mathrm{m}^{-2} \mathrm{yr}^{-1}$ and biomasses of 0.2 to $500 \mathrm{mg}$ chlorophyll $\mathrm{a} \mathrm{m}^{-2}$, equivalent to $50 \%$ of autotrophic production in many estuaries (Underwood \&
Kromkamp 1999). MPB significantly affect the flux of the major inorganic nutrients through estuaries directly through uptake and assimilation of inorganic forms of nitrogen, phosphorus and silicon (by diatoms), and indirectly as a result of photosynthesis. Photosynthesis elevates $\mathrm{O}_{2}$ concentrations and depletes dissolved inorganic carbon, affecting pore water $\mathrm{pH}$ and redox potentials in the uppermost layers of sediment. Interactions between the MPB and bacteria have been most studied in relation to nitrogen cycling within estuarine sediments. Thornton et al. (2002) estimated that the MPB assimilate approximately $13 \%$ of the inorganic nitrogen load to the Colne Estuary, a value of the same order of magnitude as that removed by bacterial denitrification (Ogilvie et al. 1997, Dong et al. 2000). Research indicates that there is competition between MPB and bacteria for inorganic nitrogen (Dalsgaard 2003, Risgaard-Petersen et al. 2004). Risgaard-Petersen (2003) analysed coupled nitrification-denitrification data from 18 European estuaries (including the Colne) and concluded that nitrogen assimilation by the MPB affects nitrogen limitation of nitrifying bacteria. Furthermore, oxygen production by the MPB affects the balance of coupled nitrification-denitrification in estuarine sediments. Oxygen production by the MPB will increase both the concentration and penetration of oxygen into the sediment, resulting in a stimulation of nitrification and inhibition of denitrification (Dong et al. 2000, Risgaard-Petersen 2003, Sundbäck et al. 2004). Inhibition of denitrification by photosynthetic oxygen production may not occur if the denitrification rate is limited by nitrate supply from the overlying water. Under these circumstances oxygen production by the MPB may increase denitrification rates through the stimulation of nitrification and the subsequent diffusion of nitrate into the denitrification zone (Rysgaard et al. 1994). Moreover, the diel variation in photosynthesis may affect the overall rate of denitrification and the proportion of coupled nitrification-denitrification (Risgaard-Petersen et al. 1994) over the course of a day.

These examples illustrate that the coupling between nutrient cycling and photosynthetic activity by the MPB is complex in estuarine sediments. The objective of this study was to determine how MPB activity affects the exchange of major inorganic nutrients across the sediment-water interface in a hypernutrified mesotidal estuary. Data from monthly surveys in the Colne Estuary during 1996 to 1998 were used to produce a comprehensive description of sediment-water fluxes of DIN, phosphorus and silicon, considering processes both in darkness and in the light. These data were used to test the hypothesis that sedimentary uptake of inorganic nutrients (other than nitrate and nitrate) from the overlying water is greater in the light than in the dark, whereas sediment uptake of nitrate and nitrite will be 
greatest in the dark due to the inhibition of denitrification in the light. In addition, the data presented in this paper have been integrated with previously published denitrification rates (Dong et al. 2000), nitrous oxide fluxes (Dong et al. 2002) and sediment-water oxygen exchanges (Thornton et al. 2002) that were measured in sediments from the same sites and at the same time as the sediment-water nutrient exchange.

\section{MATERIALS AND METHODS}

Site. Monthly sampling was carried out between August 1996 and March 1998 in the Colne (51 50' N, $1^{\circ} 0^{\prime} \mathrm{E}$ ), a mesotidal (tidal range 3.5 to $4.0 \mathrm{~m}$ ) estuary that joins the North Sea on the east coast of England (Fig. 1). There are pronounced gradients in concentrations of nutrients $\left(\mathrm{NO}_{3}{ }^{-}, \mathrm{NH}_{4}{ }^{+}, \mathrm{PO}_{4}{ }^{3-}\right.$ and $\left.\mathrm{SiO}_{3}{ }^{-}\right)$inversely related to the salinity gradient (Ogilvie et al. 1997, Kocum et al. 2002b, Thornton et al. 2002). A sewage treatment works serving the town of Colchester (Fig. 1) discharges into the estuary. During 1996, the input of

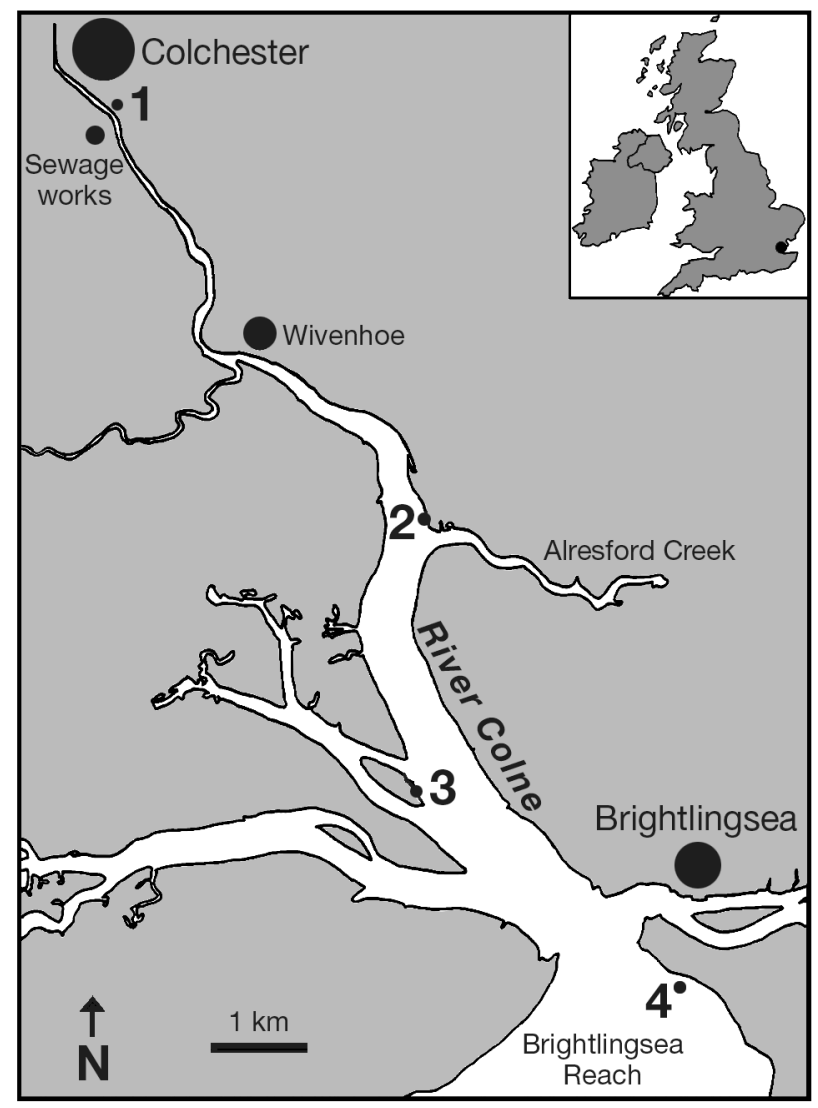

Fig. 1. Colne Estuary showing 4 sampling sites (1 to 4 ) along the estuarine salinity gradient. Inset: position of the Colne on the North Sea coast of the UK. Location of Colchester (156 000 inhabitants; UK census 2001) and associated sewage treatment works are marked at the head of the estuary
DIN into the estuary from the sewage treatment works (24.62 $\mathrm{Mmol} \mathrm{N} \mathrm{yr}^{-1}$ ) was more than twice that of the river (10 $\mathrm{Mmol} \mathrm{N} \mathrm{yr}^{-1}$ ) (A. Sage pers. comm., calculated using UK Environment Agency data). Four sites were sampled in the Colne, with both high (denoted by $\mathrm{H}$ ) and low shore (denoted by L) stations at Sites 2 and 3 (Fig. 1). Microphytobenthos were found at all sites throughout the year, with higher biomasses generally found on the high shore and at Site 1 (Thornton et al. 2002). There was no seasonal pattern in MPB biomass as indicated by chlorophyll a (chl a), with mean monthly chl a varying between $18.8 \pm 4.6 \mathrm{mg} \mathrm{m}^{-2}$ at Site 4 to $119.9 \pm 21.3 \mathrm{mg} \mathrm{m}^{-2}$ at Site $3 \mathrm{H}$ (Thornton et al. 2002). Full descriptions of the sediment characteristics at each site during the monthly sampling were published in previous papers (Dong et al. 2000, Thornton et al. 2002).

In situ sampling. An inflatable boat was used to access the mudflats at low tide. Cores were taken from the lower shore (mean low water neap) just above the low tide mark. At Sites 2 and 3 extensive mudflats were emersed at low tide. To be more representative of environmental conditions at these sites, additional cores were taken from the upper shore at the level of mean high water neap tides. All cores were collected from emersed sediment.

Sediment cores were collected using Perspex core tubes (80 mm internal diameter; $650 \mathrm{~mm}$ long), which were sealed at the bottom with silicone rubber bungs after adjusting the headspace volume above the sediment core (30 to $40 \mathrm{~cm}$ long) to $500 \mathrm{ml}$ by pushing the bung up the core tube. The long cores were used to measure rates of nutrient exchange, with 3 replicate cores taken from each sampling station at each site. Therefore, 3 long cores were collected at Sites 1 and 4, and 6 cores (3 high shore and 3 low shore) were collected from Sites 2 and 3.

Site water (40 l) was collected from the shore during daylight high tide on the day before the cores were collected. It was not possible, particularly in winter, to collect and process sediment cores and site water during daylight within a single day. Water collected at high tide was representative of the water covering both the high and low shore in this well-mixed estuary (Ogilvie et al. 1997, Robinson et al. 1998). Site water was colected from Site 1, Site 2 (Alresford Creek) and at Brightlingsea (which was representative, in terms of nutrient concentrations and salinity, of the water overlying both Sites 3 and 4). Triplicate samples were taken from each site for nutrient analysis. Water temperature was measured using an alcohol thermometer and salinity with a hand-held refractometer. The site water was placed in aerated water barrels at in situ temperature and used in the nutrient exchange measurements (see later subsection). 
Nutrient analysis. Water samples $(20 \mathrm{ml})$ were taken using a $20 \mathrm{ml}$ plastic syringe (Plastipak, Becton Dickinson). Samples were filtered through glass-fibre filters (GF/C, Whatman) and stored at $-20^{\circ} \mathrm{C}$ for nutrient analysis in $30 \mathrm{ml}$ plastic Universal bottles (Bibby Sterilin). Nutrient concentrations (nitrate, nitrite, ammonium, silicate and phosphate) were measured using a segmented flow autoanalyser (Skalar SAN ${ }^{\text {plus }}$, Skalar Analytical) (American Public Health Association 1995, Kirkwood 1996).

Sediment-water nutrient exchange. The long cores were stored (with caps removed) immersed in aerated site water at in situ temperature overnight in darkness, simulating night-time immersion. Nutrient exchange measurements were carried out the next day under illumination and in the dark. Epipelic diatoms show rhythms of vertical migration within sediments (Pinckney et al. 1994) related to diel and tidal cycles; therefore, it was important to make the illuminated measurements during daylight emersion periods. Dark nutrient exchange was measured during the in situ immersion period. Illumination was provided by $500 \mathrm{~W}$ halogen lamps at a photosynthetically active radiation (PAR) incident on the sediment surface of $500 \mu \mathrm{mol} \mathrm{m} \mathrm{m}^{-2} \mathrm{~s}^{-1}$ (Thornton et al. 2002), which approximates to the mean daily PAR received by the Colne Estuary. Kocum et al. (2002b) showed that mean daily PAR was $564 \pm 264 \mu \mathrm{mol} \mathrm{m}{ }^{-2} \mathrm{~s}^{-1}$ (mean $\pm \mathrm{SD}$ ) during the year September 1994 to September 1995, using light data collected by the University of Essex weather station (located within $1 \mathrm{~km}$ of the estuary). We did not scale PAR between months because of the warming effects of the lamps at high PAR.

Three water samples were taken from the water in each barrel at the start of the measurements. These samples were analysed to establish the initial concentration of nutrients above the sediment $\left(C_{0}\right)$. The cores were immediately capped; however, the sampling ports of the caps were left open to allow for air circulation. Water above the cores was gently mixed with a humidified air stream passed through $5 \mathrm{~mm}$-bore silicone rubber tubing suspended $2 \mathrm{~cm}$ above the sediment surface. Sediment was not re-suspended by the air-mixing. The cores were incubated in either the light or dark for $4 \mathrm{~h}$, after which a nutrient sample was taken from each core $\left(C_{4}\right)$. Caps were removed from the cores between incubations, and these were allowed to re-equilibrate with the surrounding water for at least $30 \mathrm{~min}$ before further measurements were made. Nutrient exchange across the sediment-water interface was calculated as

$$
\text { flux }\left(\mu \mathrm{mol} \mathrm{m}{ }^{-2} \mathrm{~h}^{-1}\right)=\left(198.9\left(C_{4}-C_{0}\right) h\right) / 4
$$

where $h$ is the volume (in litres) of water in the headspace above the core and 4 is incubation time (h). $C_{4}$ and $C_{0}$ were measured in $\left(\mu \mathrm{mol} \mathrm{l^{-1 }}\right)$. The factor 198.9 scaled up the area of the core to rate $\mathrm{m}^{-2}$.

Budget calculations. Rates of nutrient exchange were integrated over the total area of the Colne Estuary over $1 \mathrm{yr}$, accounting for light and tidal cycle. The Colne Estuary was divided into 4 sectors (Ogilvie et al. 1997, Dong et al. 2000) and the rates of nutrient exchange in each of these sectors was used to calculate annual fluxes. Based on the area of sediment exposed at low tide (Ogilvie et al. 1997), it was assumed that $72 \%$ of the area of the estuary was permanently immersed and the remaining $28 \%$ was emersed at low tide. Both low and high shore rates of nutrient exchange were measured at Sites 2 and 3; it was assumed that the high shore rates applied to $18 \%$ of the estuary and that low shore rates applied to the remaining intertidal (10\%) and permanently immersed areas (Dong et al. 2000). The illuminated period was defined as $3 \mathrm{~h} \mathrm{~d}^{-1}$ on the low shore and $6 \mathrm{~h} \mathrm{~d}^{-1}$ on the high shore. It was assumed that the permanently immersed area (72\%) of the estuary was in permanent darkness. The year was defined as the 12 mo period during which there was the most complete data set, from April 1997 to March 1998. Data for the missing months of December 1997 and February 1998 were replaced with data from December 1996 and February 1997 respectively. In the lower estuary (Sites 3 and 4) there were no data for the month of July. Rates of nutrient exchange during July 1997 were estimated by taking the mean of June and August 1997. Previously published data (Dong et al. 2000, 2002, Thornton et al. 2002) were combined with the data presented in this paper to produce a comprehensive description of nutrient cycling in the Colne. Denitrification rates, measured using the isotope pairing technique (Nielsen 1992), were taken from the raw data published in Dong et al. (2000). Sediment-water nitrite and nitrous oxide exchange were taken from data published in Dong et al. (2002). Sediment-water oxygen exchange and chl a concentrations in the surface $5 \mathrm{~mm}$ of sediment were taken from Thornton et al. (2002). All measurements, including the new data presented in this paper and previously published data, were made at the same sites and at the same time in the Colne Estuary.

Statistical analysis. Statistical analyses were carried out using Sigmastat 3.1 (2004; Systat Software) or SPSS 11.0 (2001; SPSS) after ensuring that the data met with the assumptions and criteria of the test being used. A Kruskal-Wallis 1-way ANOVA on ranks followed by a post-hoc Dunn's test was used to determine whether there was any significant difference in DIN flux between site, and between fluxes in the light and dark. Data from all the cores for each site were pooled to produce datasets in which $n>294$ for each nutrient in both 
the light and dark; a Mann-Whitney $U$-test was used to test the null hypothesis $\left(H_{0}\right)$ that there was no difference between fluxes in the light and dark for each nutrient.

\section{RESULTS}

\section{Water column nutrients}

There were both spatial and temporal patterns in inorganic nutrient concentrations in the water above the sediment. Nutrient concentrations decreased towards the estuary mouth. At Site 1 mean monthly ammonium concentrations ranged from 112 to $1418 \mu \mathrm{M}$ compared with 12 to $130 \mu \mathrm{M}$ at Site 4 . Nitrate concentrations followed a similar pattern with 76 to $1172 \mu \mathrm{M}$ at Site 1 and 3 to $205 \mu \mathrm{M}$ at Site 4 . There were temporal patterns in DIN concentrations, with peaks in ammonium concentration (>1 mM) during the spring and summer and winter peaks in nitrate concentration (>1 mM). Silicate and phosphate also decreased in concentration towards the estuary mouth. Mean monthly concentrations of phosphate ranged from $26-173 \mu \mathrm{M}$ at Site 1 to $<1-14 \mu \mathrm{M}$ at Site 4 . Mean monthly silicate concentra- tions in the overlying water ranged from 56-489 $\mu \mathrm{M}$ at Site 1 to $1-23 \mu \mathrm{M}$ at Site 4 . Both phosphate and silicate concentrations in the overlying water did not show temporal patterns. A more detailed presentation of nutrient concentrations in the Colne Estuary during the sampling period has been given in Thornton et al. (2002).

\section{Sediment-water nutrient exchange}

Generally, there was uptake of nitrate from the overlying water by the sediment both in the light and in the dark (Fig. 2), although there were months when nitrate fluxed out of the sediment and into the overlying water. Mean monthly nitrate fluxes across the sediment-water interface ranged from -7330 to $13000 \mu \mathrm{mol} \mathrm{m}{ }^{-2} \mathrm{~h}^{-1}$; both these rates were measured at Site 1. Rates of nitrate flux were higher in the upper estuary (Site 1) than the lower estuary (Site 4), corresponding to higher nitrate concentrations in the overlying water. There was a significant correlation $(r=0.73$, $\mathrm{n}=198, \mathrm{p}<0.001$ ) between mean monthly overlying nitrate concentration and the rate of the mean monthly nitrate flux, using data from fluxes measured in the
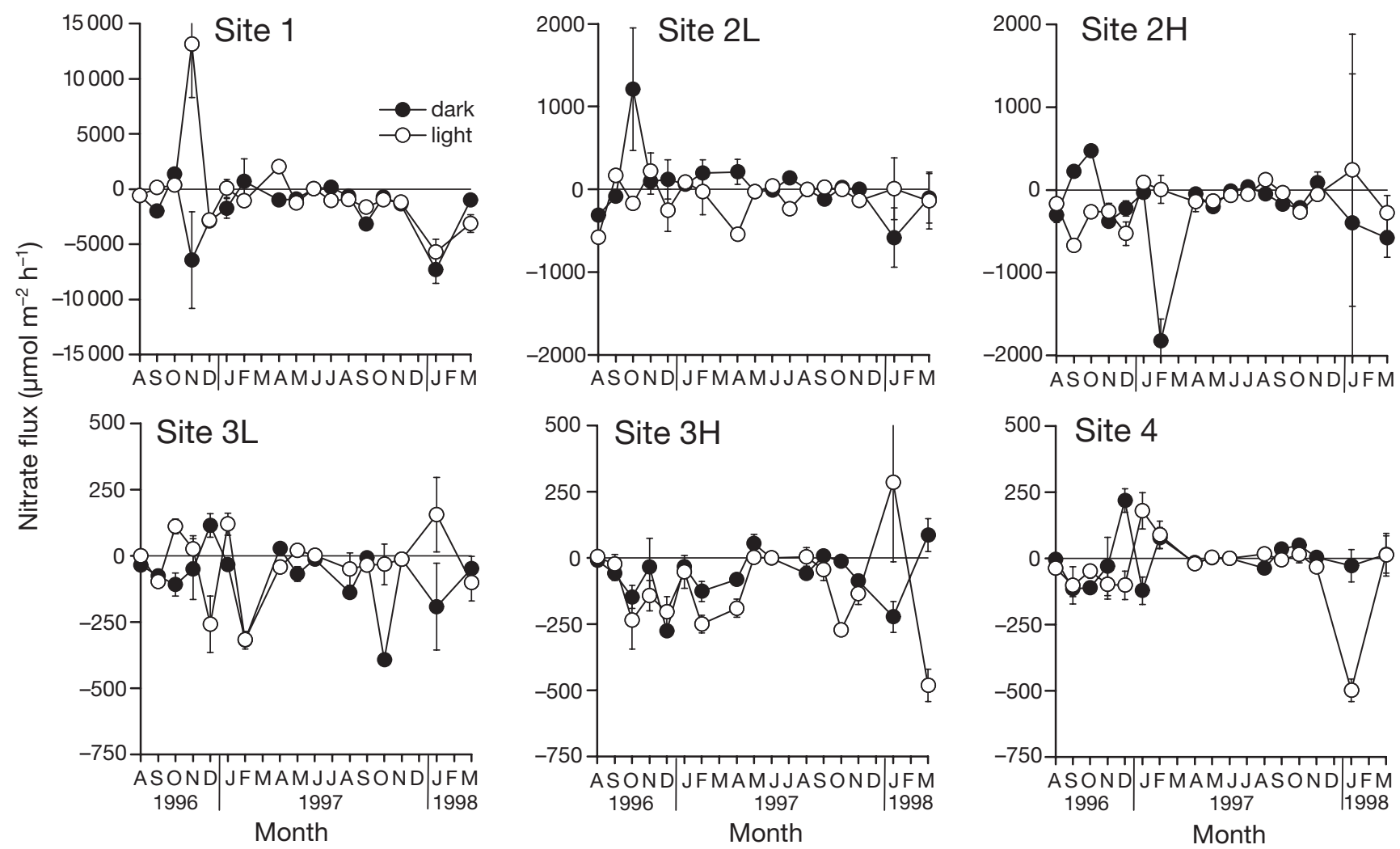

Fig. 2. Mean $( \pm \mathrm{SE}, \mathrm{n}=3)$ nitrate fluxes across sediment-water interface in the Colne Estuary under illumination and in the dark from August 1996 to March 1998. Negative fluxes indicate net sediment uptake from overlying water, positive fluxes net flux into overlying water 
dark and under illumination and ignoring the direction of the flux.

Nitrite fluxes across the sediment-water interface were low both in the light and dark, reflecting the low concentrations of nitrite compared to nitrate in the overlying water. Except at Site 1, the magnitude of nitrite fluxes were generally less than $20 \mu \mathrm{mol} \mathrm{m}^{-2} \mathrm{~h}^{-1}$. The highest nitrite fluxes were at Site 1, with a maximum rate of uptake by the sediment in November 1996 of $-1825 \mu \mathrm{mol} \mathrm{m} \mathrm{m}^{-2} \mathrm{~h}^{-1}$. There was a linear relationship between overlying nitrite concentration and nitrite uptake by the sediment in both the light and the dark. The correlation between nitrite uptake and overlying nitrite concentration was significant $(\mathrm{p}<0.001)$, with correlation coefficients of 0.83 and 0.72 for fluxes in the light and dark respectively. Although the slope of the line passing through data for the light was shallower, the difference between the slopes of the two lines was not significant.

Ammonium fluxes followed the same spatial pattern as observed for nitrate and nitrite, with fluxes of the greatest magnitude occurring in cores collected from Site 1 at the head of the estuary. Fluxes at Site 1 were at least 1 order of magnitude greater than those at Site 4. At Site 1 mean ammonium fluxes ranged from
$-11150 \mu \mathrm{mol} \mathrm{m}{ }^{-2} \mathrm{~h}^{-1}$ in the light to $22230 \mu \mathrm{mol} \mathrm{m}{ }^{-2} \mathrm{~h}^{-1}$ in the dark. Mean fluxes at Site 4 ranged from $-2212 \mu \mathrm{mol} \mathrm{m}{ }^{-2} \mathrm{~h}^{-1}$ in the dark to $389 \mu \mathrm{mol} \mathrm{m}^{-2} \mathrm{~h}^{-1}$ in the light. In the dark there was generally a net flux of ammonium from the sediment into the overlying water. However, in the light the flux of ammonium into the overlying water was generally lower than the flux in the dark or there was a change in the direction of ammonium flux, with a net uptake by the sediment from the overlying water. This pattern was most apparent at Site 2, both on the low and high shore (Fig. 3).

Fig. 4 summarizes fluxes of DIN $\left(\mathrm{NO}_{3}{ }^{-}+\mathrm{NO}_{2}{ }^{-}\right.$ $+\mathrm{NH}_{4}{ }^{+}$) across the sediment-water interface in both the light and dark. Fluxes were greatest both in terms of variability (Fig. 4A) and mean flux (Fig. 4B) at Site 1, and there was a trend in decreasing DIN fluxes towards the mouth of the estuary, corresponding to an increase in salinity and lower overlying nutrient concentrations. Fig. 4B shows that light had an effect on DIN fluxes; in the upper estuary (Sites 1 and 2) there was a mean net uptake of DIN from the overlying water into the sediment in the light. In the dark this flux was reduced compared to that in the light (Site $2 \mathrm{H}$ ) or reversed, with a net flux of DIN from the sediment into the overlying water at Sites 1 and $2 \mathrm{~L}$. In the
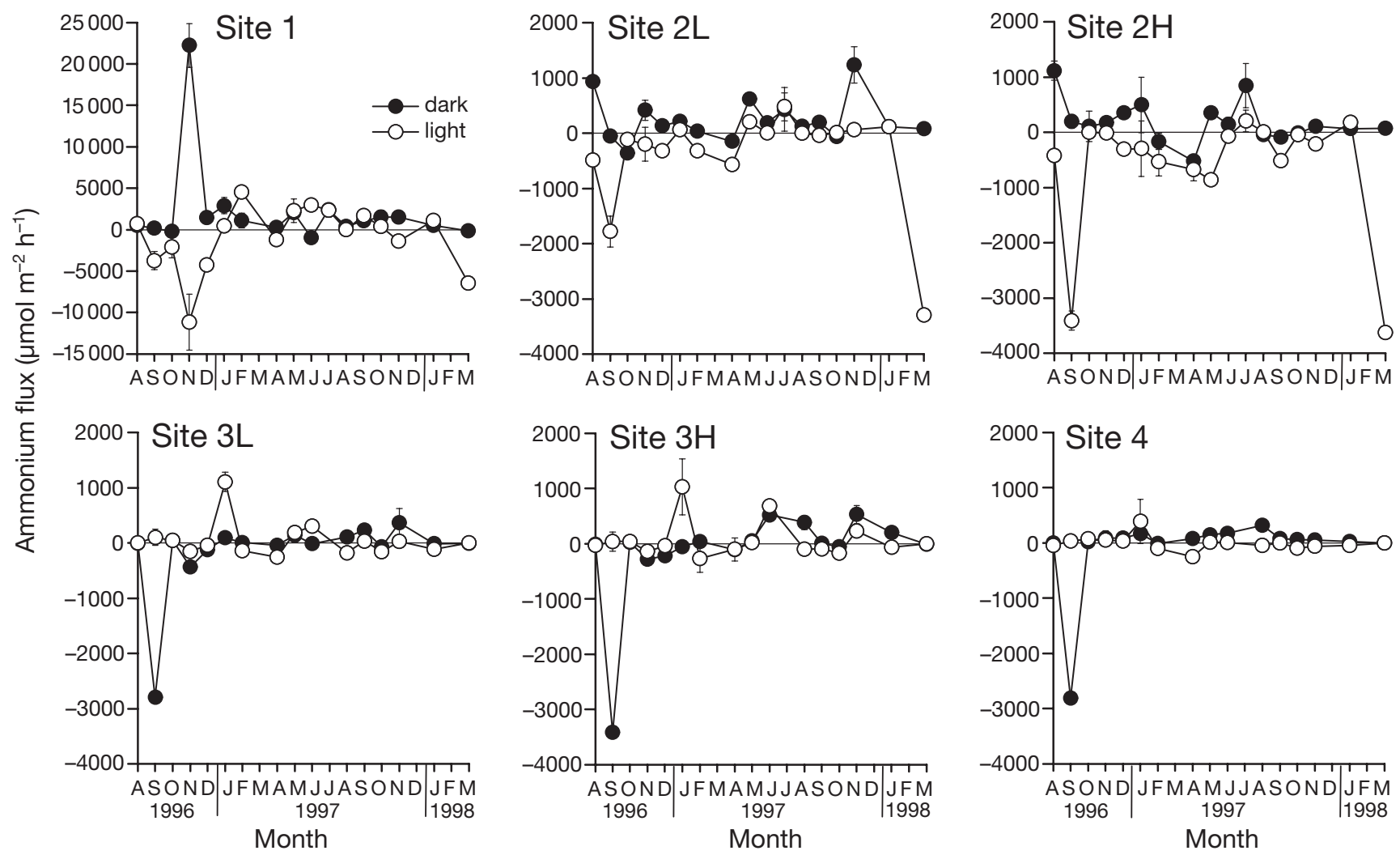

Fig. 3. Mean $( \pm \mathrm{SE}, \mathrm{n}=3)$ ammonium fluxes across sediment-water interface in the Colne Estuary under illumination and in the dark from August 1996 to March 1998. Negative fluxes indicate net sediment uptake from overlying water, positive fluxes net flux into overlying water 
lower estuary (Sites 3 and 4), there was a different pattern in DIN flux; net uptake of DIN from the overlying water was greater in the dark than in the light (Fig. 4B). There was significant difference in the fluxes ( $p<0.001$ ) (Fig. 4A), both between sites and between fluxes in the light and dark at a single site.

Phosphate fluxes were greater at Site 1 at the head of the estuary than in the lower estuary, corresponding to higher phosphate concentrations in the overlying water at the former site. Phosphate fluxes showed no pattern with light or dark and were generally $<50 \mu \mathrm{mol}$ $\mathrm{m}^{-2} \mathrm{~h}^{-1}$ in either direction across the sediment-water interface at Sites 2 to 4 . Phosphate fluxes at Site 1 were generally $>50 \mu \mathrm{mol} \mathrm{m} \mathrm{m}^{-2} \mathrm{~h}^{-1}$ and occurred in both directions across the sediment-water interface. Anomalously high fluxes (approx. $3500 \mu \mathrm{mol} \mathrm{m} \mathrm{m}^{-2} \mathrm{~h}^{-1}$ ) of phosphate from the sediment into the overlying water were observed for 3 consecutive months at Site 1 in the light from November 1996 to January 1997.

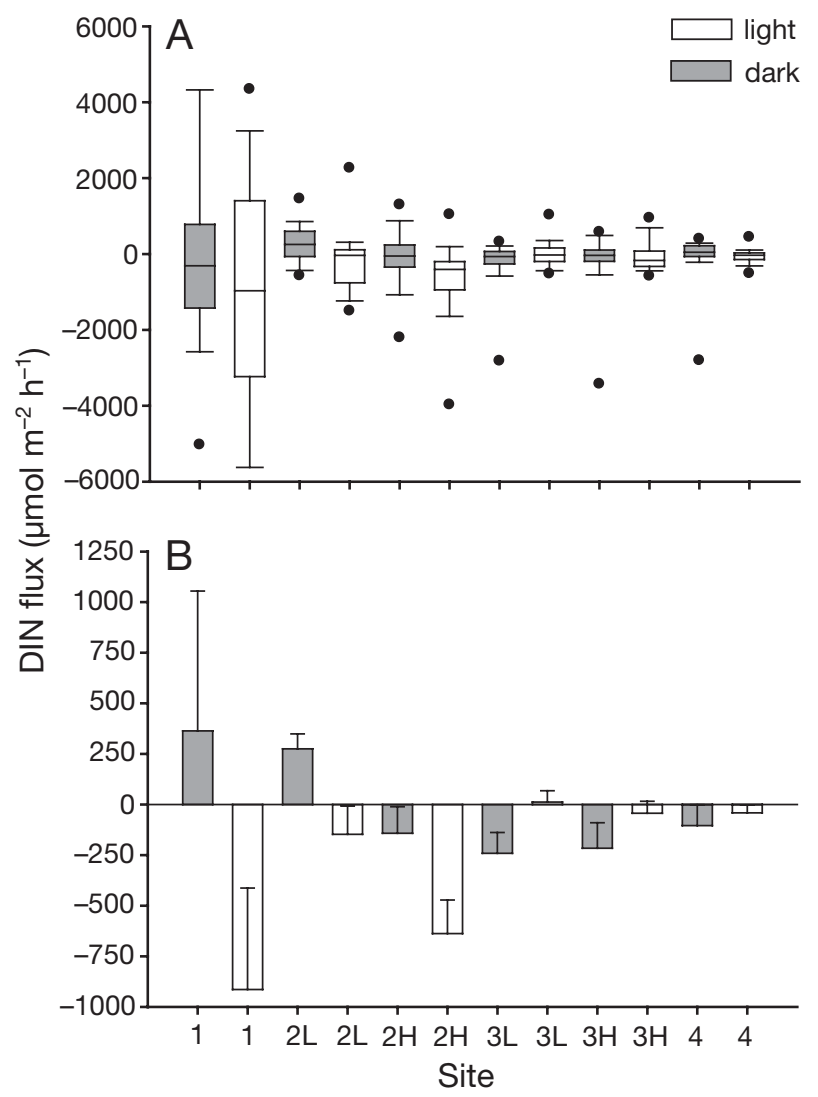

Fig. 4. Comparison of sediment-water dissolved inorganic nitrogen (DIN) fluxes (nitrate + nitrite + ammonium) between sites in Colne Estuary under illumination and in the dark; pooled data from August 1996 to March 1998 (n > 47). (A) Boxwhisker plot; central line in each box indicates median, ends of box 25th and 75th percentiles, error bars 10th and 90th percentiles, and points 5th and 95th percentiles. (B) Mean + SE flux; negative fluxes indicate net sediment uptake from overlying water, positive fluxes net flux into overlying water
Silicate fluxes were generally higher at Site 1 in both the light and in the dark compared to the rest of the estuary. Mean silicate fluxes at Site 1 ranged from -2170 to $14760 \mu \mathrm{mol} \mathrm{m} \mathrm{m}^{-2} \mathrm{~h}^{-1}$; both these flux rates were measured in the light. Generally, silicate flux rates in the rest of the estuary were between -200 and $200 \mu \mathrm{mol} \mathrm{m} \mathrm{m}^{-2} \mathrm{~h}^{-1}$. These data follow a similar pattern to the phosphate fluxes, as during most months the fluxes were relatively low, with occasional high rates of flux. Light affected the flux of silicate across the sedimentwater interface; in the dark there was generally a flux out of the sediment into the overlying water, whereas in the light these flux rates were reduced in magnitude or reversed, with net uptake by the sediment. This pattern was particularly apparent during the summer of 1997 (May to August), when most sites were a sink for silicate under illumination.

Fig. 5 summarizes the flux data for the entire estuary. Fig. 5A shows that the variability of fluxes across

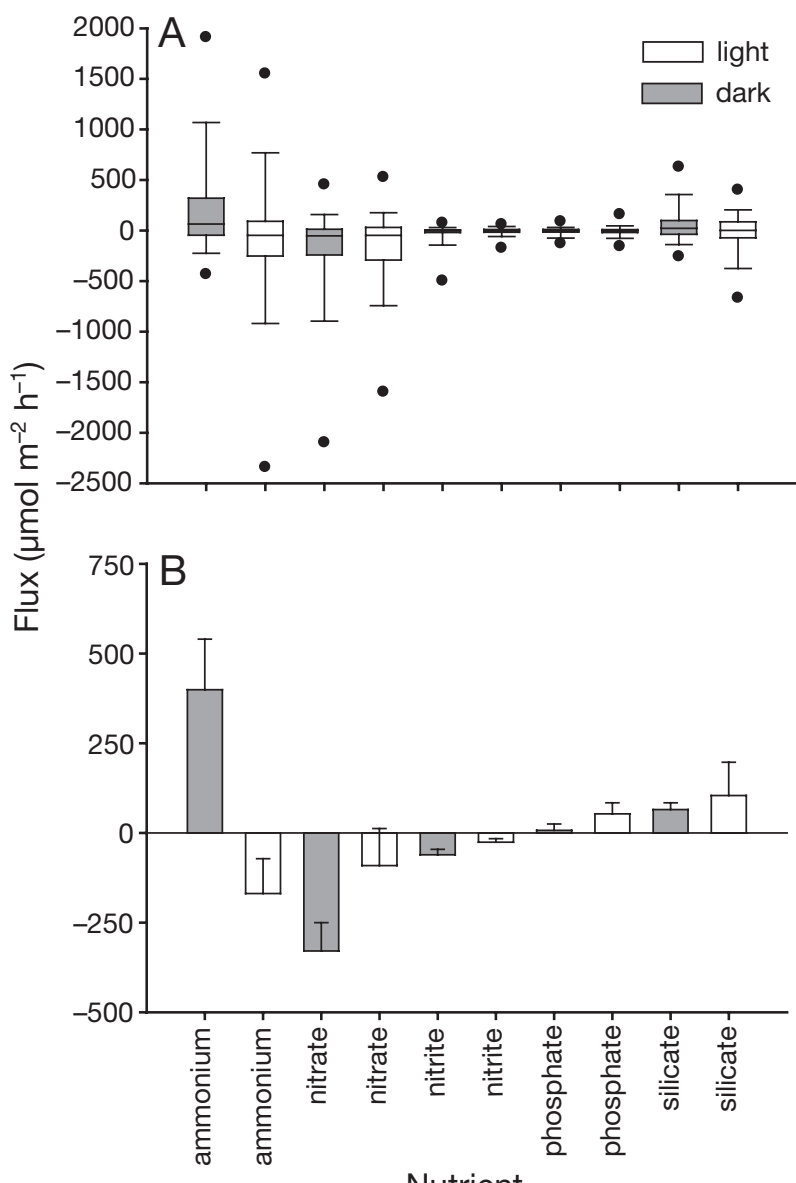

Nutrient

Fig. 5. Comparison of inorganic nutrient fluxes across sediment-water interface in the Colne Estuary under illumination and in the dark; pooled data from all sites between August 1996 to March 1998 (n > 294). Further details as in legend to Fig. 4 
the sediment-water interface was relatively high for ammonium and nitrate, and relatively low for nitrite and phosphate. Mean fluxes across the sedimentwater interface in the light and dark were different when data from the entire estuary were pooled (Fig. 5B). In the dark there was a mean net flux of ammonium from the sediment into the overlying water and ammonium uptake in the light. Mean nitrate and nitrite uptake by the sediment from the overlying water was lower in the light than in sediments incubated in the dark. However, although this dataset was large ( $\mathrm{n}>294$ for each bar plotted on Fig. 5B), it was also very variable as it pooled data from sites where fluxes were relatively high (Site 1) and sites where fluxes were relatively low (Site 4). Consequently, the standard error around each mean was high (Fig. 5B).
Table 1. Nitrate and ammonium loading $\left(\mu \mathrm{mol} \mathrm{m} \mathrm{m}^{-2} \mathrm{~h}^{-1}\right)$ to Colne Estuary during 1996; values normalised to time and sediment area. Values in parentheses are total loads in $\mathrm{Mmol} \mathrm{yr}^{-1}$

\begin{tabular}{|llll|}
\hline & $\mathrm{NH}_{4}{ }^{+}$ & $\mathrm{NO}_{3}{ }^{-}$ & Total \\
\hline Colne & $4(0.2)$ & $214(9.8)$ & $\mathbf{2 1 8 ( 1 0 )}$ \\
Sewage works & $429(19.66)$ & $108(4.96)$ & $\mathbf{5 3 7 ( 2 4 . 6 2 )}$ \\
Total & $\mathbf{4 3 3 ( 1 9 . 8 6 )}$ & $\mathbf{3 2 2 ( 1 4 . 7 6 )}$ & $\mathbf{7 5 5 ( 3 4 . 6 2 )}$ \\
\hline
\end{tabular}

Table 1 shows mean nutrient loading of ammonium and nitrate to the estuary $\mathrm{h}^{-1}$ normalised to sediment area for 1996; these data show that ammonium and nitrate fluxes across the sediment-water interface were of the same order of magnitude as rates of supply when integrated over the whole estuary. There was no sig-
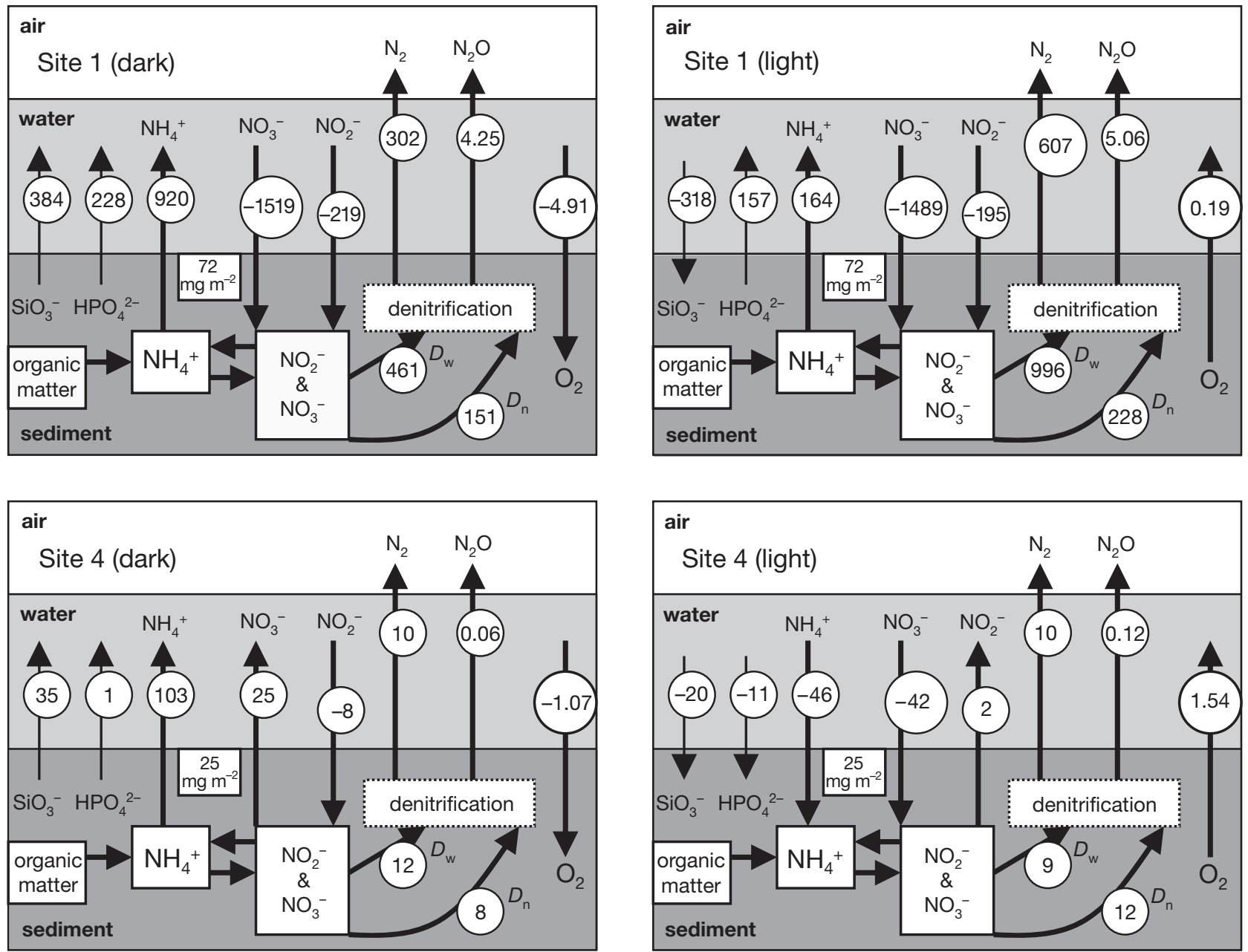

Fig. 6. Mean nutrient budgets for Sites 1 and 4 under illumination and in the dark for the year April 1997 to March 1998. Fluxes (numbers in circles) are in $\mu \mathrm{mol} \mathrm{m} \mathrm{m}^{-2} \mathrm{~h}^{-1}$, with the exception of oxygen fluxes $\left(\mathrm{mmol} \mathrm{m} \mathrm{m}^{-2} \mathrm{~h}^{-1}\right.$; chlorophyll a concentrations (numbers in boxes) are in $\mathrm{mg} \mathrm{m}^{-2}$. Each arrow is labelled with a chemical species and direction of the arrow indicates direction of net flux across the sediment-water interface. Note that $D_{\mathrm{w}}$ (denitrification using nitrate from overlying water) and $D_{\mathrm{n}}$ (coupled nitrification-denitrification) are in $\mu \mathrm{mol} \mathrm{N} \mathrm{m} \mathrm{N}^{-2} \mathrm{~h}^{-1}$, whereas products of denitrification $\left(\mathrm{N}_{2}\right.$ and $\left.\mathrm{N}_{2} \mathrm{O}\right)$ contain twice as much nitrogen per mol. Data compiled from the present study, Dong et al. $(2000,2002)$ and Thornton et al. (2002) 
nificant difference between fluxes in the light and dark for nitrate, nitrite and phosphate fluxes. However, fluxes of ammonium $(p<0.001)$ and silicate $(p<0.01)$ were significantly different in the light and dark, supporting the observation that net fluxes from the sediment into the overlying water were reduced in the light or even reversed. When the nitrogen fluxes were pooled, there was also a significant difference between net DIN fluxes across the sediment-water interface in the light compared to the dark $(\mathrm{p}<0.001)$, also evident from Fig. 4.

\section{Nutrient budgets}

Figs. 6 to 8 summarize mean hourly fluxes averaged over $1 \mathrm{yr}$ across the sediment-water interface at Sites 1 to 4 . Fig. 6 shows that fluxes of all chemical species measured were greater at Site 1 than at Site 4 by at least 1 order of magnitude, and close to 2 orders of magnitude for nitrate and nitrite. Annual average oxygen uptake at Site 1 was high compared to that at Site 2 (Fig. 7), Site 3 (Fig. 8) and Site 4 (Fig. 6), indicating that Site 1 was more heterotrophic than the other sites in the Colne Estuary; this resulted in the lowest net flux of oxygen into the overlying water in the light. At Site 1, nitrate + nitrite uptake by the sediment was $>1.5 \mathrm{mmol} \mathrm{m}^{-2} \mathrm{~h}^{-1}$; although denitrification rates were relatively high (Fig. 6), they were not sufficient to support the observed nitrate uptake. This general pattern was observed throughout the estuary (Figs. 6 to 8). Nitrification was a more significant process near the estuary mouth (Site 4) than at the head of the estuary (Site 1); at Site 4 coupled nitrification-denitrification rates $\left(D_{\mathrm{n}}\right)$ were approximately equal to denitrification rates supported from the overlying water $\left(D_{\mathrm{w}}\right)$ and, on average, there was a flux of nitrate from the sediment to the overlying water in the dark (Fig. 6). In contrast, at Site $1, D_{\mathrm{n}}$ rates were less than a third of $D_{\mathrm{w}}$ rates. At
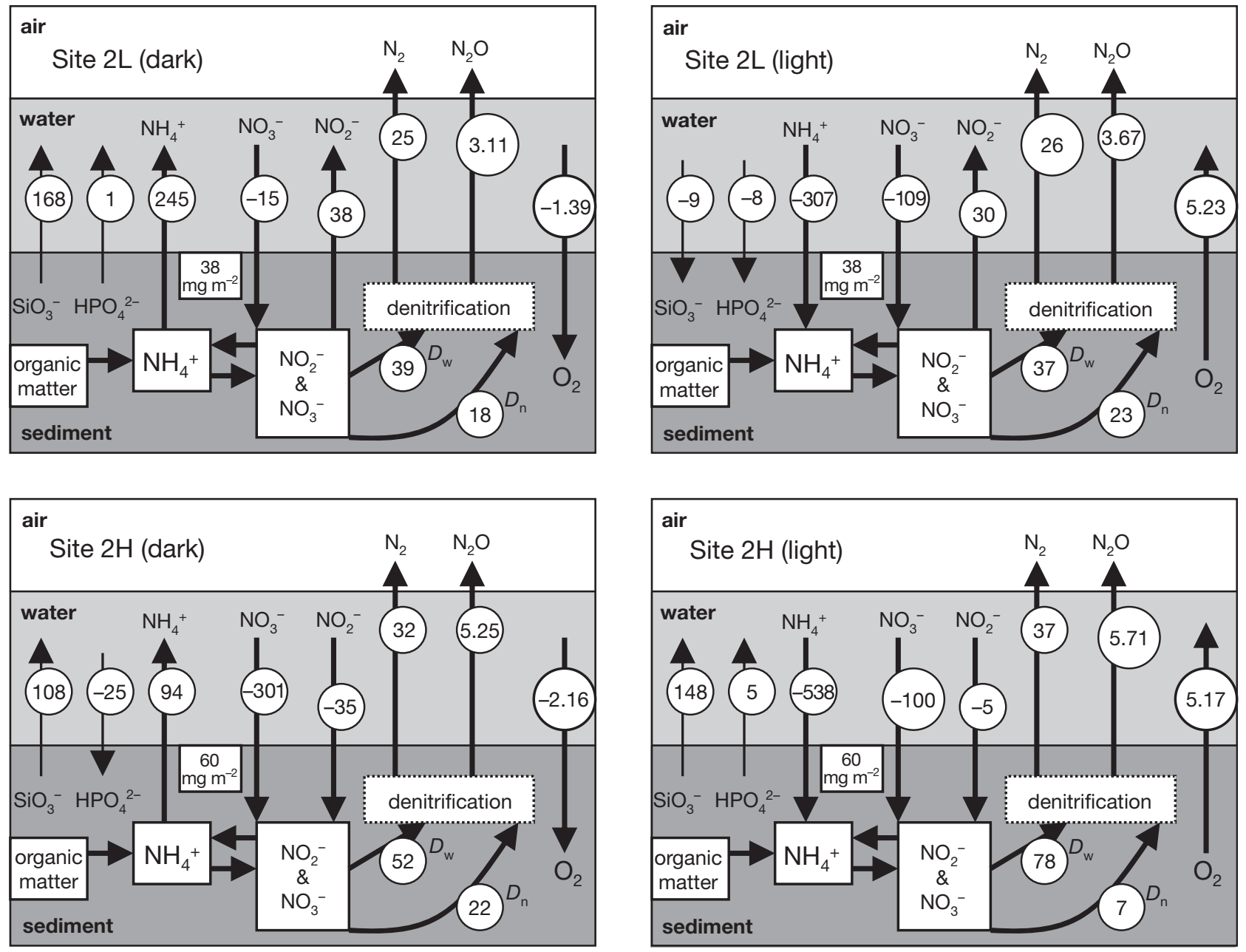

Fig. 7. Nutrient budget for Site 2 under illumination and in the dark for the year April 1997 to March 1998. Data compiled from the present study, Dong et al. $(2000,2002)$ and Thornton et al. (2002). Further details as in legend to Fig. 6 
Sites 1 and 4 there was net silicate uptake by the sediment in the light and a flux into the overlying water in the dark. This pattern was also seen at Site 2L (Fig. 7) and Site 3H (Fig. 8).

In the middle of the estuary, at Sites 2 and 3, net primary productivity was more significant than at the mouth (Site 4) or head (Site 1) of the estuary, as indicated by the relatively high rates of net oxygen flux from the sediment into the overlying water in the light (Figs. 7 \& 8). Gross oxygen flux from the sediment into the overlying water was 3 to 5 times greater than the respiration rates at Sites 2 and 3. At Sites 2 and 3 there was net uptake of nitrate and nitrite from the overlying water in both the light and dark, except at Site 2L (Fig. 7), where nitrite was observed to flux from the sediment into the overlying water. In the light there was net uptake of ammonium on both the high and low shore, compared to a net flux into the overlying water in the dark.
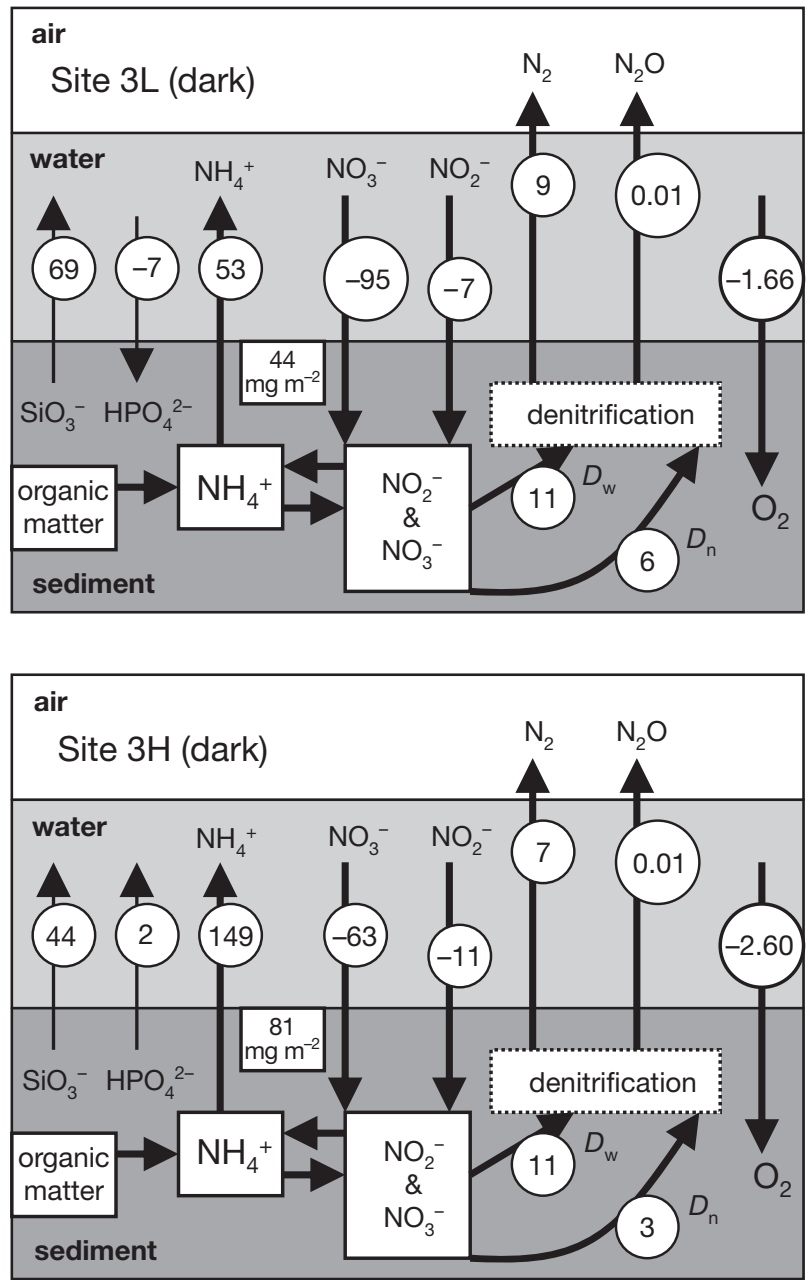

At all sites, nitrous oxide fluxes were relatively low compared to the overall rate of denitrification. $\mathrm{N}_{2}$ fluxes were calculated assuming that the final products of denitrification are $\mathrm{N}_{2}$ and $\mathrm{N}_{2} \mathrm{O}$ and that any measured denitrification $\left(D_{\mathrm{w}}+D_{\mathrm{n}}\right)$ which cannot be accounted for by the measured rates of $\mathrm{N}_{2} \mathrm{O}$ flux must be in the form of $\mathrm{N}_{2} \cdot \mathrm{N}_{2}$ formed the majority of the gaseous products at all sites, although the ratio of $\mathrm{N}_{2}: \mathrm{N}_{2} \mathrm{O}$ was different at different sites. At Site 2 the $\mathrm{N}_{2}: \mathrm{N}_{2} \mathrm{O}$ ratio was 6 to 8 (Fig. 7), which is at least 1 order of magnitude lower than Sites 1, 3 and 4. Consequently, $\mathrm{N}_{2} \mathrm{O}$ formed $11-14 \%$ of the products of denitrification at Site 2 compared to $0.1-2 \%$ at the other sites.

Table 1 shows the annual input of nitrate and ammonium to the Colne Estuary for 1996. The total $\mathrm{NO}_{3}{ }^{-}+$ $\mathrm{NH}_{4}{ }^{+}$load to the estuary was $34.62 \mathrm{Mmol}$, of which $29 \%$ came from the River Colne and $71 \%$ from the sewage treatment works (Fig. 1). Fluvial inputs into the estuary were low during 1996 because of extremely
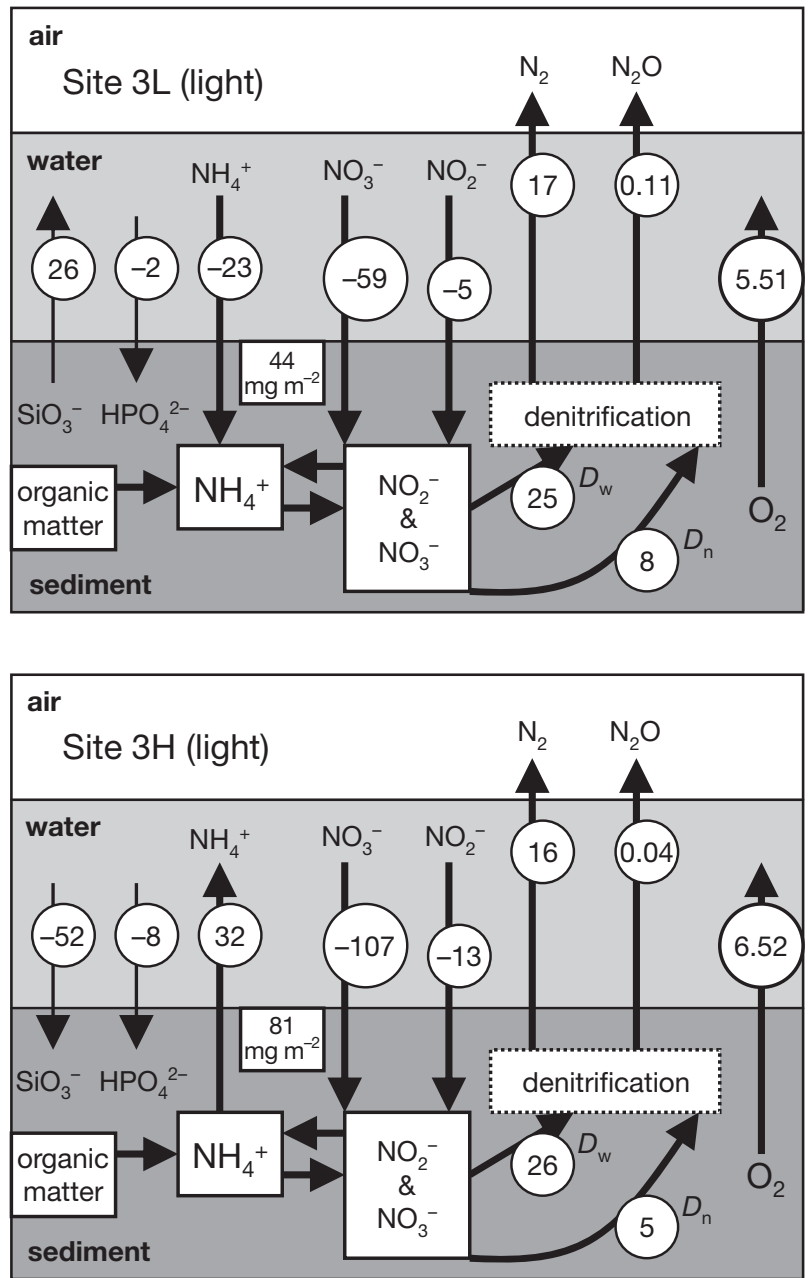

Fig. 8. Nutrient budget for Site 3 under illumination and in the dark for the year April 1997 to March 1998. Data compiled from the present study, Dong et al. $(2000,2002)$ and Thornton et al. (2002). Further details as in legend to Fig. 6 
low winter rainfall (A. Sage pers. comm.). In most years inputs into the estuary from the River Colne approximately equal those from the sewage treatment works. As nitrate was $98 \%$ of the $\mathrm{NO}_{3}{ }^{-}+\mathrm{NH}_{4}{ }^{+}$load from the River Colne but only $20 \%$ of the load from the sewage treatment works, the low rainfall and river flow resulted in nitrate decreasing in importance in the estuary during this period. As the sewage treatment works dominated inputs into the Colne Estuary during this period, $57 \%$ of the $\mathrm{NO}_{3}{ }^{-}+\mathrm{NH}_{4}{ }^{+}$load to the estuary was in the form of ammonium. These values can be compared with fluxes across the sediment-water interface for the whole estuary (Table 2), and are of the same order of magnitude. Table 2 shows that the magnitude of fluxes across the sediment-water interface was much lower in the light than in the dark. Although on an average hourly rate $\mathrm{m}^{-2}$ fluxes across the sediment-water interface were of the same order of magnitude in both the light and dark (Figs. 6 to 8), when scaled up over the whole area of the estuary over a whole year there was a difference in fluxes, as only a portion of the estuarine sediments were exposed to light for only a proportion of the day. The estuarine sediments were a sink for both nitrate and nitrite, with a total of uptake of $-16.28 \mathrm{Mmol} \mathrm{N} \mathrm{yr}^{-1}$; however the estuarine sediments were a source of ammonium with a net flux into the overlying water of $12.1 \mathrm{Mmol} \mathrm{N} \mathrm{yr}^{-1}$. The estuary was a net sink for DIN with an uptake of

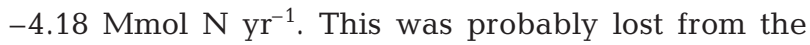
estuary to the atmosphere via denitrification. Direct measurements of denitrification supported this hypothesis, with a measured annual estuarine denitrifi-

Table 2. Annual budget (April 1997 to March 1998) of sedi-

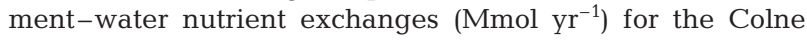
Estuary, accounting for processes under illumination and in the dark. Budget calculated using data from the present study in combination with data previously published in Dong et al. $2000\left(^{*}\right)$ and Dong et al. $2002\left({ }^{* *}\right)$. Negative and positive values indicate that estuarine sediments were net sink and source respectively. $D_{\mathrm{w}}$ : dentrification using nitrate from overlying water; $D_{\mathrm{n}}$ : coupled nitrification-dentrification

\begin{tabular}{|lccc|}
\hline & Dark & Light & Total \\
\hline $\mathrm{NH}_{4}{ }^{+}$ & 12.4 & -0.306 & 12.1 \\
$\mathrm{NO}_{3}{ }^{-}$ & -13.8 & -0.780 & -14.5 \\
$\mathrm{NO}_{2}{ }^{-* *}$ & -1.69 & -0.085 & -1.78 \\
Total (DIN) & $\mathbf{- 3 . 0 9}$ & $\mathbf{- 1 . 1 7}$ & $\mathbf{- 4 . 1 8}$ \\
$D_{\mathrm{w}}{ }^{*}$ & 4.60 & 0.488 & 5.09 \\
$D_{\mathrm{n}}{ }^{*}$ & 1.63 & 0.115 & 1.75 \\
Total $^{*}$ & $\mathbf{6 . 2 3}$ & $\mathbf{0 . 6 0 2}$ & $\mathbf{6 . 8 3}$ \\
$\mathrm{N}_{2} \mathrm{O}^{* *}$ & 0.077 & 0.006 & 0.083 \\
$\mathrm{SiO}_{3}{ }^{-}$ & 6.17 & -0.084 & 6.09 \\
$\mathrm{HPO}_{4}{ }^{2-}+\mathrm{PO}_{4}{ }^{3-}$ & 1.85 & 0.055 & 1.91 \\
\hline
\end{tabular}

cation of 6.83 $\mathrm{Mmol} \mathrm{N} \mathrm{yr}^{-1}$ (Table 2). Fluxes of ammonium into the overlying water and measured denitrification rates $\left(D_{\mathrm{w}}\right)$ accounted for a $17.19 \mathrm{Mmol}$

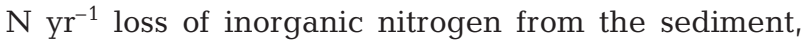
which approximately balanced uptake from the overlying water of nitrate + nitrite $\left(-16.28 \mathrm{Mmol} \mathrm{N} \mathrm{yr}^{-1}\right)$. Table 2 shows that there was a net annual flux of both

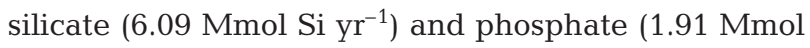
$\mathrm{N} \mathrm{yr}^{-1}$ ) from the estuarine sediments into the overlying water.

\section{DISCUSSION}

\section{Nutrient loads}

It is well established that the Colne Estuary is hypernutrified (Ogilvie et al. 1997, Robinson et al. 1998, Dong et al. 2000, 2002, Thornton et al. 2002), with high DIN inputs coming both from the surrounding catchment and a sewage treatment works. The Colne is representative of an estuary subject to a high degree of anthropogenic perturbation and is typical of many surrounding the developed North Atlantic (Nedwell et al. 1999). Spikes in winter nitrate and nitrite concentration were associated with winter rains and subsequent runoff from the surrounding land, which flushed nitrate from the catchment soils. In summer rainfall is generally low while biological activity (both on land and in the river) is high, leading to lower nitrate concentrations than during winter (Nedwell et al. 1999). The main source of ammonium to the estuary was the sewage treatment works, with spikes in ammonium concentrations probably related to discharge rate from the sewage treatment works and the relative rates of nitrogen transformations within the plant.

Phosphorus chemistry in estuaries is poorly characterized compared to that of nitrogen. The sewage treatment works were likely to be a significant source of dissolved phosphorus, in addition to the catchment of the Colne. There are complex processes of particle adsorption and desorption affecting dissolved inorganic phosphorus concentrations as freshwater and seawater mix in an estuary (Day et al. 1989). Moreover, there may have been significant anthropogenic inputs from polyphosphates, which may be biologically available but are rarely measured and are poorly characterised (Sundareshwar et al. 2001).

Mean nitrate uptake by the sediment across the whole estuary in the dark was $-329 \pm 79 \mu \mathrm{mol} \mathrm{m}^{-2} \mathrm{~h}^{-1}$ $( \pm$ SE, $\mathrm{n}=297)$ between August 1996 and March 1998, matching well with a rate of supply of $322 \mu \mathrm{mol} \mathrm{m}^{-2} \mathrm{~h}^{-1}$ (data for 1996; Table 1). The match between nitrate load and sediment uptake is consistent with the observation that the Colne Estuary is well-mixed (Ogilvie et 
al. 1997, Kocum et al. 2002b), as in a stratified estuary the nutrient load from the river is spatially separated from the sediment and more likely to pass through the estuary without being affected by sedimentary processes.

\section{Sediment-water nutrient exchange}

An objective of this work was to test the hypothesis that sediment-water nutrient fluxes are significantly different in estuarine sediments exposed to light than in the same sediments in the dark due to the activity of the MPB. Sediment-water exchange of ammonium was effected by illumination; ammonium flux from the sediment into the overlying water was generally reduced or even reversed in the light. Whether ammonium is released from the sediment into the overlying water or is taken up by the sediment will depend on the concentration gradient across the sediment-water interface and metabolic processes occurring within the sediment. Ammonium concentrations in sediment porewaters are generally higher than those in the overlying water, with an additional pool of exchangeable ammonium adsorbed to the sediment (Rosenfeld 1979). High ammonium concentrations result from the catabolism of nitrogen containing organic matter in the sediment, produced by both aerobic and anaerobic respirations. Specific metabolisms may further affect ammonium concentrations; DNRA results in ammonium production from nitrate in the anaerobic zone and nitrification results in the oxidation of ammonium to nitrate in the aerobic zone. The net effect of these processes in the sediments of the Colne and most other organic-rich, nutrified estuaries (e.g. the Great Ouse; Nedwell \& Trimmer 1996), is a flux of ammonium from the sediment to the overlying water. Both prokaryotes and protists living within the sediment take up and assimilate ammonium from the porewater; this process was insufficient to prevent a net flux of ammonium into the overlying water in the dark. However, in the light there was net uptake of ammonium from the overlying water, primarily through uptake and assimilation by the MPB (Thornton et al. 1999) and secondarily through stimulation of nitrification as a result of increased oxygen penetration into the sediment (Risgaard-Petersen et al. 1994, Rysgaard et al. 1994, Dong et al. 2000, An \& Joye 2001). Using the lens tissue technique (Eaton \& Moss 1966) to extract MPB from Colne sediment, Thornton et al. (1999) demonstrated that ammonium uptake by natural populations of MPB was greater under illumination than in the dark. In addition, there was a rundown of porewater ammonium in the upper $3 \mathrm{~cm}$ of sediments incubated under illumination compared to sediments in the dark, with the great- est rundown occurring closest to the sediment-water interface, which is where the MPB are located (Thornton et al. 1999).

As ammonium was the dominant species of DIN in the Colne Estuary during the study period, processes affecting the flux of ammonium across the sedimentwater interface had a profound effect on whether the sediments were a net source or sink for DIN. In the upper estuary (Sites 1 and 2), ammonium uptake in the light was sufficient to reverse the direction of DIN flux. In the lower estuary (Sites 3 and 4), this was not the case and DIN uptake was higher in the dark compared to that in the light. This indicates a shift moving down the estuary from Sites 1 and 2, where processes affecting ammonium production and uptake determined DIN flux, to Sites 3 and 4, where processes affecting nitrate were more significant in determining DIN fluxes. At Sites 3 and 4 (Fig. 4) uptake of DIN was greatest in the dark, which may indicate that denitrification supplied by nitrate in the overlying water $\left(D_{\mathrm{w}}\right)$ was the main determinant of DIN sediment-water exchange in the lower Colne, as $D_{\mathrm{w}}$ was inhibited under illumination by oxygen production by the MPB (Dong et al. 2000). This observation is supported by nitrate fluxes, on a whole estuary scale, where mean hourly nitrate fluxes into the sediment were greater in the dark than under illumination (Fig. 5). The MPB themselves may have also taken up and assimilated ammonium and nitrate in the light, resulting in the lower estuary being a consistent sink for DIN in both the light and dark.

Silicate fluxes across the sediment-water interface were also affected by illumination, particularly in the summer of 1997, with sites being a net sink for silicate under illumination and a net source of silicate in the dark. This pattern was probably due to the influence of the MPB in the Colne, which was dominated by diatoms (Thornton et al. 2002). Most organisms do not have a significant requirement for silicon; however, diatoms use silicon to form the frustule that encloses individual cells. Overall, the sediments were a net source of silicate; mean flux in the dark over the whole estuary was $65 \pm 19 \mu \mathrm{mol} \mathrm{m}{ }^{-2} \mathrm{~h}^{-1}( \pm \mathrm{SE}, \mathrm{n}=306)$, which is very similar to fluxes measured by Conley et al. (1997) in the Gulf of Finland (Baltic) in the range of 72 to $84 \mu \mathrm{mol} \mathrm{m}{ }^{-2} \mathrm{~h}^{-1}$.

Sundbäck et al. (1991) used a continuous flow experimental system to determine the influence of sublittoral MPB on sediment-water solute exchange and found diel patterns of flux in cores maintained on a light-dark cycle. Under illumination there were reduced fluxes of ammonium out of the sediment compared to the dark or a net uptake, as observed in the Colne Estuary. Sundbäck et al. (1991) also measured diel cycles in nitrate and phosphate fluxes in response 
to illumination; such effects were not apparent in the Colne, possibly due to significantly higher nutrient concentrations than in the Kattegat site of Sundbäck et al. (1991). MPB compete with bacteria for nitrogen (Risgaard-Petersen 2003) and may be a significant temporary sink for DIN (Dalsgaard 2003, Sundbäck et al. 2004). Estimates of the proportion of DIN assimilated by the microphytobenthos in the Colne Estuary vary from $2.3 \%$ (Dong et al. 2000) to 12.8\% (Thornton et al. 2002), depending on how DIN assimilation is calculated.

Bioturbation and bioirrigation by both macro- and meiofauna are processes that affect sediment-water solute fluxes and the relative rates of biogeochemical processes within the sediment (Aller 2001). Cores from the Colne Estuary showed relatively little evidence of significant bioirrigation activity, with the exception of Alresford Creek (Cooper 1999). In Alresford Creek (Fig. 1) the polychaete worm Hediste diversicolor was abundant in the intertidal and significantly increased the area of sediment-water interface during tidal immersion and affected solute exchange across the sediment-water interface (Cooper 1999).

\section{Anammox and denitrification rates}

The denitrification rates presented in Figs. 6 to 8 were measured using the isotope pairing technique (Nielsen 1992). The assumptions of the method are challenged by the discovery of the anammox process in marine sediments (Risgaard-Petersen et al. 2003). A consequence of anammox and denitrification cooccurring is an overestimation of total $\mathrm{N}_{2}$ production and true denitrification rates (Risgaard-Petersen et al. 2003). Our denitrification rates were measured before anammox was considered in nitrogen cycling studies of marine sediments; consequently we are faced with the question of whether the measured denitrification rates presented in Dong et al. (2000) are valid and can be used to calculate the budgets presented in this paper. Relatively little is known about the factors affecting anammox rates or even how widespread the process is, although Dalsgaard et al. (2005) suggested that it may be responsible for $50 \%$ of the removal of fixed nitrogen from the ocean. The limited data for marine sediments, summarized by Dalsgaard et al. (2005), indicates that although the absolute rates of anammox may be higher in very shallow water compared to the continental shelf and slope, the relative contribution of anammox to $\mathrm{N}_{2}$ production in shallow waters such as estuaries is relatively low. RisgaardPetersen et al. (2003) concluded that the isotope pairing technique does not significantly overestimate $\mathrm{N}_{2}$ production in estuarine sediments, as anammox ac- counts for $<6 \%$ of $\mathrm{N}_{2}$ production. Trimmer et al. (2003) measured anammox in the Thames estuary, which is located near the Colne Estuary and therefore shares many of its characteristics. Anammox rates accounted for 1 to $8 \%$ of the $\mathrm{N}_{2}$ production from the sediment (Trimmer et al. 2003). Dong et al. (2000) directly tested the central assumption of the paired isotope technique, i.e. that the concentration of ${ }^{15} \mathrm{NO}_{3}{ }^{-}$tracer added to the overlying water does not effect the denitrification rate of ${ }^{14} \mathrm{NO}_{3}{ }^{-}$. This assumption was not violated, leading Risgaard-Petersen et al. (2003) to conclude that the denitrification rates presented in Dong et al. (2000) were representative of in situ rates. Based on current knowledge, it is reasonable to conclude that anammox did not contribute significantly to nitrogen removal in the Colne Estuary.

\section{Budgets}

The sediments of the Colne Estuary are a net source of ammonium, soluble reactive phosphate and silicate. Potentially, fluxes of inorganic nutrients in to the overlying water would have supported phytoplankton production in the estuary. Kocum et al. (2002b) measured phytoplankton biomass and productivity in the Colne Estuary between September 1994 and November 1995 and found that biomass was between 0.5 and $37.5 \mu \mathrm{g}$ chl a $\mathrm{l}^{-1}$, with productivity ranging from negligible to $17 \mu \mathrm{g} \mathrm{Cl}^{-1} \mathrm{~h}^{-1}$. Photosynthesis-irradiance curves indicated that productivity was light-limited in situ due to the high turbidity of the well-mixed water column (Kocum et al. 2002b). Light limitation of phytoplankton growth is further supported by measurable inorganic nutrient concentrations in the overlying water at Site 4, indicating that not all nutrients were taken up in the Colne itself and that the estuary is a source of nutrients supporting phytoplankton growth in the surrounding coastal waters (Kocum et al. 2002b). Although the sediments are a net sink for nitrate and nitrite, this did not affect nitrogen limitation of the phytoplankton as the sediment was a net source of ammonium.

The Colne Estuary is a source of $\mathrm{N}_{2} \mathrm{O}$, a potent greenhouse gas, as shown from the data used in this paper (Dong et al. 2002) and previous work (Robinson et al. 1998). Nitrous oxide is produced during denitrification (Seitzinger et al. 1984, Dong et al. 2002), nitrification (De Bie et al. 2002) and DNRA (Senga et al. 2006); therefore, determining the factors affecting $\mathrm{N}_{2} \mathrm{O}$ production in coastal sediments is complex. Site 2 was a major source of $\mathrm{N}_{2} \mathrm{O}$ as indicated by flux data, the relatively high supersaturation of the water column with $\mathrm{N}_{2} \mathrm{O}$ over the site (Dong et al. 2002) and the high ratio of $\mathrm{N}_{2}: \mathrm{N}_{2} \mathrm{O}$ indicated by the nutrient budgets. Experiments with intact sediments by Dong et al. (2002) showed that 
the proportion of $\mathrm{N}_{2} \mathrm{O}$ produced relative to $\mathrm{N}_{2}$ by sediment from Site 2 increased with increases in the overlying concentration of nitrite significantly more than with increases in nitrate concentration. This may be an explanation for the elevated $\mathrm{N}_{2} \mathrm{O}$ production at Site 2; however, it is not possible to determine from the budgets if nitrite generation within the sediment was relatively high at Site 2 compared to other sites.

The annual budget for the whole Colne Estuary (Table 2) and mean hourly fluxes at each site enable the comparison of published denitrification rates (Dong et al. 2000) with sediment-water exchange of nitrogen species over the same time period. $D_{\mathrm{w}}$ was calculated

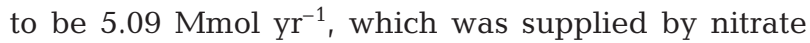
and nitrite uptake from the overlying water. Direct measurements of nitrate and nitrite exchange across the sediment-water interface showed that the sediments were net sinks for both nitrate and nitrite. However, the flux of nitrate and nitrite were -14.5 and $-1.78 \mathrm{Mmol} \mathrm{yr}^{-1}$ respectively. Therefore, uptake of oxidized inorganic nitrogen by the sediment was 3.2 times higher than the denitrification rate, indicating that the majority of nitrate and nitrite fluxing into the sediment from the overlying water was not denitrified. Alternative fates for this nitrogen include the assimilation by organisms within the sediment (i.e. bacteria and microphytobenthos), anammox (see above) and DNRA. The estuarine sediments were a net source of ammonium,

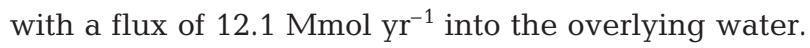
Sources of ammonium in the sediment would have been the mineralisation of organic matter and DNRA. Uptake of inorganic oxidized nitrogen (-16.28 Mmol N $\mathrm{yr}^{-1}$ ) could be approximately balanced by adding together ammonium flux and denitrification $\left(D_{\mathrm{w}}\right)$ to give a total of $17.19 \mathrm{Mmol} \mathrm{N} \mathrm{yr}^{-1}$. This indicates that DNRA is a significant process in the Colne Estuary, as shown previously by King \& Nedwell (1985). Subtracting $D_{\mathrm{w}}$ from the total sediment uptake of oxidized inorganic nitrogen suggests a DNRA rate of $11.19 \mathrm{Mmol}$ $\mathrm{N} \mathrm{yr}^{-1}$. Applying this approach to the mean hourly fluxes at each site (Figs. 6 to 8) shows that DNRA was significant at all sites except Site $2 \mathrm{~L}$ in the dark.

Ammonium production within the sediment was higher than the 12.1 $\mathrm{Mmol} \mathrm{yr}^{-1}$ fluxing into the overlying water due to uptake by the microphytobenthos, particularly under illumination (Fig. 7). Nitrification also consumed ammonium in the sediment by converting it to nitrate. Although the total nitrification rates were not measured, nitrification coupled to denitrification $\left(D_{\mathrm{n}}\right)$ was measured by Dong et al. (2000) using the isotope pairing technique. Using these data, coupled nitrification-denitrification was calculated to be 1.75 $\mathrm{Mmol} \mathrm{N} \mathrm{yr}^{-1}$. Therefore, nitrification effected a significant loss of the ammonium, accounting for a minimum of $1.75 \mathrm{Mmol} \mathrm{N} \mathrm{yr}^{-1}$. As not all nitrification would be coupled to denitrification, the actual rate of nitrification in the Colne Estuary would have been higher. Consequently, DNRA rates may have been higher than suggested by the mass balance of sediment-water nitrate and ammonium fluxes, and $D_{\mathrm{w}}$ rates.

DNRA, by converting $\mathrm{NO}_{3}{ }^{-}$to $\mathrm{NH}_{4}{ }^{+}$, not only retains nitrogen within coastal ecosystems but also converts it to a form which is the preferable inorganic nitrogen source for phytoplankton (Dortch 1990). Respiration of organic matter within the sediment, whether the terminal electron acceptor is oxygen, nitrate or sulphate, will also initially produce ammonium (Day et al. 1989). The sedimentary uptake of nitrate and exchange for ammonium in the overlying water may have affected phytoplankton growth, productivity and community structure in the estuary. Kocum et al. (2002a) showed that $>95 \%$ of the inorganic nitrogen uptake in the Colne was in the form of ammonium, despite the relatively high concentrations of nitrate in the Colne Estuary.

Although there were significant differences between mean hourly ammonium fluxes under illumination and in the dark (Figs. 6 to 8), these were not significant over the whole estuary as the number of hours and area of illuminated sediment was relatively low. Ignoring the direction of the flux, fluxes in the light accounted for less than $5 \%$ of the total sediment-water exchange of both ammonium and nitrate. However, if net processes are considered, then processes under illumination are significant, as in the dark a large proportion of the $-15.49 \mathrm{Mmol} \mathrm{N} \mathrm{yr}^{-1}$ of oxidized inorganic nitrogen was cancelled out by the flux of 12.4 $\mathrm{Mmol} \mathrm{N} \mathrm{yr}^{-1}$ as ammonium into the overlying water. The net DIN flux was -3.09 Mmol $\mathrm{N} \mathrm{yr}^{-1}$ in the dark and -1.17 $\mathrm{Mmol} \mathrm{N} \mathrm{yr}^{-1}$ in the light, as fluxes of all nitrogen species were negative under illumination. Therefore, fluxes under illumination accounted for $28 \%$ of the net uptake of DIN by estuarine sediments, despite the short time periods and small area of sediment illumination.

Acknowledgements. The authors thank M. Cooper and J. Green for technical support. This research was funded in part under contract (EPG 1/9/76) to the UK Department of the Environment, Transport and the Regions as a contribution to its co-ordinated programme of marine research for the North East Atlantic. This research was funded in part by the EU research programme 'Preserving the Ecosystem' under NICE Project contract MAS3-CT96-0048.

\section{LITERATURE CITED}

Aller RC (2001) Transport and reactions in the bioirrigated zone. In: Boudreau BP, Jørgensen BB (eds) The benthic boundary layer: transport processes and biogeochemistry, Oxford University Press, New York, p 269-301

American Public Health Association (1995) Standard methods 
for the examination of water and waste water. American Public Health Association, Washington, DC

An S, Joye SB (2001) Enhancement of coupled nitrification-denitrification by benthic photosynthesis in shallow estuarine sediments. Limnol Oceanogr 46:62-74

Conley DJ, Stockenberg A, Carman R, Johnstone RW, Rahm L, Wulf F (1997) Sediment-water nutrient fluxes in the Gulf of Finland, Baltic Sea. Estuar Coast Shelf Sci 45:591598

Cooper M (1999) The influence of deposit feeding benthic fauna on biogeochemical fluxes across the estuarine sediment-water interface. MSc thesis, University of Essex, Colchester

Dalsgaard T (2003) Benthic primary production and nutrient cycling in sediments with benthic microalgae and transient accumulation of macroalgae. Limnol Oceanogr 48: $2138-2150$

Dalsgaard T, Thamdrup B, Canfield DE (2005) Anaerobic ammonium oxidation (anammox) in the marine environment. Res Microbiol 156:457-464

Day JW, Hall CAS, Kemo WM, Yáñez-Aracibia A (1989) Estuarine ecology. John Wiley \& Sons, New York

De Bie MJM, Middelburg JJ, Starink M, Laanbroek HJ (2002) Factors controlling nitrous oxide at the microbial community and estuarine scale. Mar Ecol Prog Ser 240:1-9

Dong LF, Thornton DCO, Nedwell DB, Underwood GJC (2000) Denitrification in the sediments of the River Colne estuary, England. Mar Ecol Prog Ser 203:109-122

Dong LF, Nedwell DB, Underwood GJC, Thornton DCO, Rusmuna I (2002) Nitrous oxide formation in estuaries: the central role of nitrite. Appl Environ Microbiol 68:12401249

Dortch Q (1990) The interaction between ammonium and nitrate uptake in phytoplankton. Mar Ecol Prog Ser 61: 183-201

Eaton JW, Moss B (1966) The estimation of numbers and pigment content in epipelic algal populations. Limnol Oceanogr 11:584-595

Gardner WS, McCarthy MJ, An S, Sobolev D, Sell KS, Brock D (2006) Nitrogen fixation and dissimilatory nitrate reduction to ammonium (DNRA) support nitrogen dynamics in Texas estuaries. Limnol Oceanogr 51:558-568

King D, Nedwell DB (1985) The influence of nitrate concentration upon the end-products of nitrate dissimilation by bacteria in anaerobic salt marsh sediment. FEMS Microbiol Ecol 31:23-28.

Kirkwood DS (1996) Nutrients: a practical note on their determination in seawater. ICES Techniques in Marine Environmental Sciences, No. 17. ICES, Copenhagen

Kocum E, Nedwell DB, Underwood GJC (2002a) Regulation of phytoplankton primary production along a hypernutrified estuary. Mar Ecol Prog Ser 231:13-22

Kocum E, Underwood GJC, Nedwell DB (2002b) Simultaneous measurement of phytoplanktonic primary production, nutrient and light availability along a turbid, eutrophic UK east coast estuary (the Colne Estuary). Mar Ecol Prog Ser 231:1-12

Nedwell DB, Trimmer M (1996) Nitrogen fluxes through the upper estuary of the Great Ouse, England: the role of the bottom sediments. Mar Ecol Prog Ser 142:273-286

Nedwell DB, Jickells TD, Trimmer M, Sanders R (1999) Nutrients in estuaries. Adv Ecol Res 29:43-92

Nielsen LP (1992) Denitrification in sediment determined from nitrogen isotope pairing. FEMS Microbiol Ecol 86: 357-362

Ogilvie B, Nedwell DB, Harrison RM, Robinson A, Sage A (1997) High nitrate, muddy estuaries as nitrogen sinks: the nitrogen budget of the River Colne estuary (United Kingdom). Mar Ecol Prog Ser 150:217-228

Pinckney J, Piceno Y, Lovell CR (1994) Short-term changes in the vertical distribution of benthic microalgal biomass in intertidal muddy sediments. Diatom Res 9:143-153

Risgaard-Petersen N (2003) Coupled nitrification-denitrification in autotrophic and heterotrophic estuarine sediments: on the influence of benthic microalgae. Limnol Oceanogr 48:93-105

Risgaard-Petersen N, Rysgaard S, Nilesen LP, Revsbech NP (1994) Diurnal variation of denitrfication and nitrification in sediments colonized by benthic microphytes. Limnol Oceanogr 39:573-579

Risgaard-Petersen N, Nielsen LP, Rysgaard S, Dalsgaard T, Meyer RL (2003) Application of the isotope pairing technique in sediments where anammox and denitrification coexist. Limnol Oceanogr Methods 1:63-73

Risgaard-Petersen N, Nicolaisen MH, Revsbech NP, Lomstein BA (2004) Competition between ammonia-oxidizing bacteria and benthic microalgae. Appl Environ Microbiol 70: 5528-5537

Robinson AD, Nedwell DB, Harrison RM, Ogilvie BG (1998) Hypernutrified estuaries as sources of $\mathrm{N}_{2} \mathrm{O}$ emission to the atmosphere: the estuary of the River Colne, Essex, UK. Mar Ecol Prog Ser 164:59-71

Rosenfeld JK (1979) Ammonium adsorption in nearshore anoxic sediments. Limnol Oceanogr 24:356-364

Rysgaard S, Risgaard-Petersen N, Sloth N P, Jensen K, Nielsen L P (1994) Oxygen regulation of nitrification and denitrification in sediments. Limnol Oceanogr 39:1643-1652

Seitzinger SP (1988) Denitrification in freshwater and coastal marine ecosystems: ecological and geochemical significance. Limnol Oceanogr 33:702-724

Seitzinger SP, Nixon SW, Pilson MEQ (1984) Denitrification and nitrous oxide production in coastal marine sediments. Limnol Oceanogr 29:73-83

Senga Y, Mochida K, Fukumori R, Okamoto N, Seike Y (2006) $\mathrm{N}_{2} \mathrm{O}$ accumulation in estuarine and coastal sediments: the influence of $\mathrm{H}_{2} \mathrm{~S}$ on dissimilatory nitrate reduction. Estuar Coast Shelf Sci 67:231-238

Sundareshwar PV, Morris JT, Pellechia PJ, Cohen HJ, Porter DE, Jones BC (2001) Occurrence and ecological implications of pyrophosphate in estuaries. Limnol Oceanogr 46: $1570-1577$

Sundbäck K, Enoksson V, Granéli W, Pettersson K (1991) Influence of sublittoral microphytobenthos on the oxygen and nutrient flux between sediment and water: a laboratory continuous-flow study. Mar Ecol Prog Ser 74:263-279

Sundbäck K, Linares F, Larson F, Wulff A (2004) Benthic nitrogen fluxes along a depth gradient in a microtidal fjord: the role of denitrification and microphytobenthos. Limnol Oceanogr 49:1095-1107

Thornton DCO, Underwood GJC, Nedwell DB (1999) Effect of illumination and emersion period on the exchange of ammonium across the estuarine sediment-water interface. Mar Ecol Prog Ser 184:11-20

Thornton DCO, Dong LF, Underwood GJC, Nedwell DB (2002) Factors affecting microphytobenthic biomass, species composition and production in the Colne Estuary (UK). Aquat Microb Ecol 27:285-300

Trimmer M, Nicholls JC, Deflandre B (2003) Anaerobic ammonium oxidation measured in sediments along the Thames Estuary, United Kingdom. Appl Environ Microbiol 69: $6447-6454$

Underwood GJC, Kromkamp J (1999) Primary production by phytoplankton and microphytobenthos in estuaries. Adv Ecol Res 29:94-153 